\title{
Microbial respiration and production in the Delaware Estuary
}

\author{
Kathryn Preen, David L. Kirchman* \\ College of Marine Studies, University of Delaware, Lewes, Delaware 19958, USA
}

\begin{abstract}
The paucity of data on respiration has hampered efforts to understand the relationships between respiration and microbial biomass production and the impact of respiration on oxygen concentrations and net community production. The goal of this study was to estimate total and bacterial respiration in the water column of the Delaware Estuary where primary and bacterial production has been examined extensively in the past. We found that respiration often exceeded in situ primary production at several sites in the estuary and in different seasons, and that net oxygen production consequently was negative, especially at an upstream station in the Delaware River where oxygen concentrations are often below saturation. Respiration by heterotrophic bacteria accounted for about $50 \%$ of total respiration and correlated significantly with ${ }^{14} \mathrm{C}$ primary production, but there was no significant correlation between bacterial production (thymidine and leucine incorporation) and primary production. A simple budget was used to explore relationships among production, respiration and input of terrestrial carbon. These calculations revealed that some values, e.g. high bacterial production relative to primary production along with low bacterial respiration relative to total respiration, were not consistent with common estimates of bacterial growth efficiency, although nonsteady-state conditions should not be ignored. However, other values of bacterial respiration $(50 \%$ of total) and production (bacterial production:primary production ratio equal to about 0.8 ) in the Delaware River were consistent with high growth efficiencies (30\%) of bacteria using a large input of terrestrial organic material. This input may explain why heterotrophic bacteria appear to have a larger impact than primary production on net oxygen saturation in the Delaware Estuary.
\end{abstract}

KEY WORDS: Respiration · Oxygen $\cdot$ Net community production $\cdot$ Bacterial production $\cdot$ Metabolic balance $\cdot$ Estuaries

Resale or republication not permitted without written consent of the publisher

\section{INTRODUCTION}

The balance between primary production and respiration sets the amount of organic matter available for export to other ecosystems, storage in sediments or as dissolved organic material (DOM), and transfer to higher trophic levels. The magnitude and controls of primary production have been extensively examined, whereas respiration has not been measured as frequently, and consequently is not as well understood as primary production (Williams 2000). In addition to uncertainty about the magnitude of respiration and thus of the balance between primary production and respiration, the controls of respiration remain poorly resolved.
Heterotrophic bacteria often account for about $50 \%$ of total respiration in aquatic environments (Williams 2000). This estimate is based on a few direct measures of respiration by size fractions dominated by heterotrophic bacteria and on indirect measures based on bacterial production (Williams 2000). The latter approach is rightly criticized (Jahnke \& Craven 1995) because respiration is much larger than production and because the relationship between bacterial respiration and biomass production, which is set by the bacterial growth efficiency, varies greatly (del Giorgio \& Cole 2000). However, the data set on bacterial production, which is much larger than that on respiration (Williams 2000), still has many uses in exploring relationships between heterotrophic microbes and primary 
production and the contribution of bacteria to total heterotrophic activity (Cole \& Pace 1995).

Data on bacterial respiration and production may be particularly important in examining oxygen and carbon cycles in estuaries. Total respiration is often high, and occasionally exceeds in situ primary production in estuaries, making some estuaries net heterotrophic (Smith \& Hollibaugh 1993). These high respiration rates, especially those exceeding primary production, are thought to be fueled by the input of terrestrial organic carbon, much of it being dissolved organic material (DOM) that is used primarily by heterotrophic bacteria. Consequently, estuarine bacterial production and respiration rates are high, both in absolute terms and relative to primary production and to total respiration (Ducklow \& Shiah 1993). In the Chesapeake Bay, for example, the average percentage of total respiration accounted for by the bacterial size fraction $(<3 \mu \mathrm{m})$ is $50 \%$, although this percentage varies greatly (1 to $77 \%$ ) (Smith \& Kemp 2001). Unlike other estuaries (Smith \& Hollibaugh 1993), the Chesapeake Bay is net autotrophic, and the impact of terrestrial carbon appears to be minimal (Smith \& Kemp 1995). The role of bacterial respiration and terrestrial carbon in estuaries that are potentially net heterotrophic is less clear. Although production has been measured quite frequently in estuaries (Ducklow \& Shiah 1993), there are few direct estimates of respiration in estuaries other than the Chesapeake (Hopkinson et al. 1989, Griffith et al. 1990, Smith \& Hollibaugh 1993, Revilla et al. 2002).

The goal of this study was to examine microbial production and respiration in the Delaware Estuary. Bacterial production was very high relative to primary production, especially in the upper (freshwater) regions of the Delaware Estuary in 1986 to 1988 (Hoch \& Kirchman 1993), and, in one of the few studies of its kind in an estuary, Lipschultz et al. (1986) found that net community (oxygen) production was negative in the Delaware River in 1983. These data suggest that heterotrophic bacteria could contribute substantially to total respiration, which in turn may exceed primary production, especially in the Delaware River; however, direct measurements are lacking, and changes over the last decade in the balance between production and total respiration are unknown. We found that bacteria overall accounted for about $50 \%$ of total respiration in the Delaware Estuary, and that bacterial respiration was especially high in the Delaware River where net community production was often negative.

\section{MATERIALS AND METHODS}

Sample collection and size fractionation. The Delaware Estuary was sampled from March 2001 through
March 2002 from the RV 'Cape Henlopen'. We chose 4 stations (River, Turbidity Maximum, Mid-Bay, and Open Bay) for detailed analysis; these stations are 198, 80, 44 and $9 \mathrm{~km}$ from the mouth of the Delaware Estuary, respectively. Experiments were conducted with surface water collected using a sampling rosette with 101 Niskin bottles. Immediately following a cast, water samples were combined from several Niskin bottles into $20 \mathrm{l}$ carboys to ensure homogeneity of the sample during subsampling. In March 2001, samples were filtered sequentially through 3.0 and $0.8 \mu \mathrm{m}$ polycarbonate membrane filters (Poretics) to obtain the bacterial size fraction. During subsequent cruises the bacterial size fraction was collected using a diaphragm pump and filtered through a polypropylene string-wound $1.0 \mu \mathrm{m}$ prefilter (Cole Parmer) and then a $0.8 \mu \mathrm{m}$ polycarbonate membrane filter (Nuclepore). The effects of the size fractionation procedure were examined in August 2002. The 2 procedures resulted in similar respiration rates and bacterial abundances; less than $7.8 \%$ of total chlorophyll $a$ was present in the bacterial size fraction (Preen 2003).

Subsampling took place within $30 \mathrm{~min}$ of water collection and size fractionation. All incubations were carried out in borosilicate glass, $60 \mathrm{ml}$ biological oxygen demand (BOD) bottles that were acid-washed prior to sampling (Smith \& Kemp 2001). BOD bottles for total community respiration and production measurements were filled from carboys containing whole water directly from the rosette. Bottles for determining bacterial respiration rates were filled with $<0.8 \mu \mathrm{m}$ filtered water. All bottles were allowed to overflow 3 times the volume of the bottle, ensuring that no bubbles remained in the bottles, and capped free of headspace with ground glass stoppers.

Oxygen production and respiration. Rates of plankton community production and total and bacterial respiration rates were based on light and dark bottle incubations. Oxygen concentrations were determined using high-precision micro-Winkler titrations using a computer-controlled, potentiometric endpoint detection system (Metrohm Titrino 785; Brinkmann Instruments). We fixed 4 replicate bottles with Winkler reagents at 0,12 , and 24 or $48 \mathrm{~h}$. All samples were titrated within $12 \mathrm{~h}$ of fixing. Oxygen saturation was determined using temperature and salinity data (Sharp et al. 1982).

Samples for respiration rate measurements were incubated in the dark at in situ temperature for $48 \mathrm{~h}$ (March and June 2001). Incubations during subsequent cruises were shortened to $24 \mathrm{~h}$ (August 2001 to March 2002). Volumetric respiration rates $\left(\mu_{m o l ~ O} \mathrm{l}^{-1}\right.$ $\mathrm{h}^{-1}$ ) were calculated using a simple linear regression of dissolved oxygen concentration versus time. Integrated rates of total and bacterial respiration $\left(\mathrm{mmol} \mathrm{O}_{2}\right.$ 
$\mathrm{m}^{-2} \mathrm{~d}^{-1}$ ) were determined by multiplying the volumetric rates $\left(\mu \mathrm{mol} \mathrm{O} \mathrm{O}_{2} \mathrm{l}^{-1} \mathrm{~h}^{-1}\right)$ by $24 \mathrm{~h}$ and the depth of the water column. Oxygen concentrations decreased linearly over time in both total community and bacterial size fraction incubations (Preen 2003); Smith \& Kemp (2001) also found rates to be linear for up to at least $30 \mathrm{~h}$ in the Chesapeake Bay. Initial oxygen concentrations were generally higher in the bacterial size fraction due to the introduction of atmospheric oxygen during size fractionation and subsampling. However, because respiration is calculated as the change in dissolved oxygen over time, preserving the initial ambient oxygen concentration was not essential for this study.

Oxygen production was estimated from bottles incubated in the light for $24 \mathrm{~h}$ under the same conditions as ${ }^{14} \mathrm{C}$ primary production bottles. Oxygen production rates were measured at 3 of the 5 irradiance levels used for ${ }^{14} \mathrm{C}$ primary production $(60,21$ and $3 \%$ of surface irradiance). Volumetric rates at each of the 3 light levels were integrated over the depth of the photic zone using the attenuation coefficient, similar to the approach used to calculate ${ }^{14} \mathrm{C}$ primary production. Net community oxygen production for the water column was then calculated as net oxygen production in the photic zone less the amount of respiration occurring throughout the remaining portion of the water column. Respiration rates were assumed to be constant with depth in these well-mixed water columns.

Biomass, biomass production, and nutrients. $\mathrm{Chl} a$ concentrations were measured as described by Pennock \& Sharp (1986). Primary production was estimated from ${ }^{14} \mathrm{CO}_{2}$ uptake over $24 \mathrm{~h}$ at 5 light levels obtained using neutral density screens $(60,35,21,11$ and $3 \%$ of surface irradiance) and incubated at the in situ temperature in a deck incubator (Pennock \& Sharp 1986). Data from 4 other research cruises along the same transect as this study suggested that differences in volumetric ${ }^{14} \mathrm{CO}_{2}$ uptake in samples incubated at 60 versus $100 \%$ are small. The uptake in the $100 \%$ light bottle was at most $65 \%$ higher than that in the $60 \%$ light bottle, and at most $62 \%$ lower than the $60 \%$ light bottle (J. Sharp unpubl. data). To evaluate the impact of not having the $100 \%$ light bottle data, the maximum and minimum $100 \%$ light bottle values were estimated from that in the $60 \%$ light bottle data. Even assuming the maximal deviations, the difference in integrated rates without the $100 \%$ light bottle data was small. Integrated primary production $(\mathrm{mmol} \mathrm{C}$ $\mathrm{m}^{-2} \mathrm{~d}^{-1}$ ) was at most $7 \%$ higher $($ mean $=5 \% ; \mathrm{n}=16$ ) and at most $8 \%$ lower (mean $=6 \% ; \mathrm{n}=16$ ) than without the $100 \%$ light bottle. Photosynthetically active radiation (PAR) was measured with a QSR-250 integrating light meter and used to estimate the attenuation coefficient.
Incorporation rates of thymidine (TdR) and leucine (leu) were used to estimate bacterial production (Fuhrman \& Azam 1980, Kirchman 2001). Thymidine and leucine were added to $1.5 \mathrm{ml}$ of seawater at a final concentration of $20 \mathrm{nM}$. Triplicate samples and 1 killed control were incubated in the dark at in situ temperature for $15 \mathrm{~min}$ to $1 \mathrm{~h}$, depending on the season, and processed using the centrifugation method (Smith \& Azam 1992). Conversion factors of $1.1 \times 10^{18} \mathrm{cells} \mathrm{mol}^{-1}$ for TdR incorporation and $6.5 \times 10^{17} \mathrm{cells} \mathrm{mol}^{-1}$ for leu incorporation previously calculated for the Delaware Estuary (Hoch \& Kirchman 1993) were used to estimate cell production from rates of TdR and leu incorporation. Cell production was converted to carbon production using $20 \mathrm{fg} \mathrm{C} \mathrm{cell}^{-1}$. This combination of conversion factors results in a factor slightly less than $1.5 \mathrm{~kg} \mathrm{C} \mathrm{mol}^{-1}$, a commonly used conservative factor for leu incorporation (Kirchman 2001).

Inorganic nutrient concentrations $\left(\mathrm{NO}_{3}{ }^{-}, \mathrm{NH}_{4}{ }^{+}\right.$, $\mathrm{PO}_{4}{ }^{3-}$ ) were determined colorimetrically using an automated Perstorp analytical flow-through analyzer.

\section{RESULTS}

We sampled 4 representative stations along the salinity gradient of the Delaware Estuary between March 2001 and March 2002. The River station had relatively low turbidity (low attenuation coefficient) (Fig. 1A) and high nutrients, although other stations downstream of the River station had even higher nutrients; Fig. 1B presents only nitrate + nitrite concentrations, but the other major nutrients varied similarly (Sharp et al. 1982, Preen 2003). Turbidity was sometimes highest at about $100 \mathrm{~km}$ upstream from the mouth of the estuary, but it was still high at the Turbidity Maximum station, which also had high nutrients. The Mid-Bay station had lower turbidity and nutrients, along with often the highest chlorophyll concentrations (Sharp et al. 1982, Preen 2003). Turbidity and especially nutrients were lowest at the Open Bay station (Fig. 1). Table 1 presents other basic data on the stations.

Primary production, as measured by the ${ }^{14} \mathrm{C}$ method, was usually highest at the Mid-Bay station (Fig. 2A). Primary production rates varied from $2 \mathrm{mmol} \mathrm{C} \mathrm{m}^{-2} \mathrm{~d}^{-1}$ at the River station in December to $137 \mathrm{mmol} \mathrm{C} \mathrm{m}^{-2} \mathrm{~d}^{-1}$ at the Mid-Bay station in March. The maxima and minima in total respiration (Fig. 2B) followed those in primary production, in particular the high values in the Mid-Bay station, and overall there was a significant correlation between ${ }^{14} \mathrm{C}$ primary production and respiration $(\mathrm{r}=0.667 ; \mathrm{p}<0.01 ; \mathrm{n}=16)$. Total respiration varied from about $5 \mathrm{mmol} \mathrm{O}_{2} \mathrm{~m}^{-2} \mathrm{~d}^{-1}$ at the Open Bay station in December to $351 \mathrm{mmol} \mathrm{O}_{2} \mathrm{~m}^{-2} \mathrm{~d}^{-1}$ at the River station in August. Respiration rates were lowest $\left(<40 \mathrm{mmol} \mathrm{O}_{2} \mathrm{~m}^{-2} \mathrm{~d}^{-1}\right)$ in December at all 4 stations. 

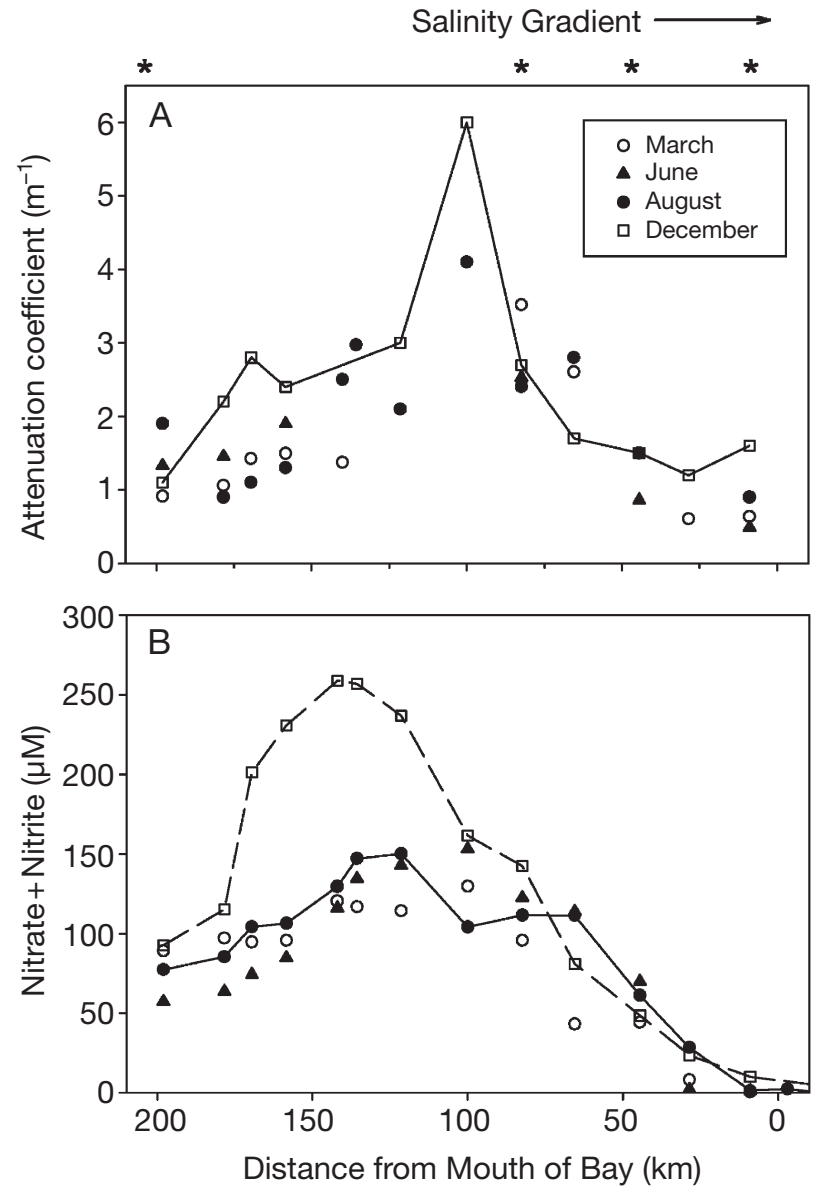

Fig. 1. (A) Attenuation coefficient and (B) nitrate + nitrate concentrations in the Delaware Estuary from March to December 2001. Salinity gradient starts at $\sim 100 \mathrm{~km}$ and increases to $\sim 30$ at mouth of the bay $(0 \mathrm{~km})$. Asterisks (top abscissa) indicate main stations where respiration was measured

Incorporation rates of thymidine and leucine were significantly correlated in these samples and over the entire data set $(\mathrm{r}=0.63 ; \mathrm{p}<<0.001 ; \mathrm{n}=78)$. Bacterial production $\left(P_{\mathrm{b}}\right)$, which was calculated from the average of both thymidine and leucine, was often very high relative to primary production $\left(P_{\mathrm{P}}\right)$, and the ratio of the 2 production rates $\left(P_{\mathrm{b}}: P_{\mathrm{P}}\right)$ sometimes exceeded 1 (Table 2). There was a significant negative relationship between $P_{\mathrm{b}}: P_{\mathrm{P}}$ values and distance upstream from the estuarine mouth $(\mathrm{r}=-0.493$; $\mathrm{p}<$ $0.05, \mathrm{n}=19)_{;} P_{\mathrm{b}}: P_{\mathrm{P}}$ was highest at the River station (average of over 1) and lowest at the Mid-Bay and Open Bay stations (average of about 0.15). Because of this variation in $P_{\mathrm{b}}: P_{\mathrm{P}}$, there was no significant correlation between bacterial production and primary production ( $\mathrm{p}>0.05)$. The high $P_{\mathrm{b}}: P_{\mathrm{P}}$ values imply that heterotrophic bacteria process a large fraction of primary production in the Delaware Estuary, especially at the River and Turbidity Maximum stations.
Table 1. Basic environmental parameters of stations in the Delaware Estuary where microbial production and oxygen dynamics were measured. See also Fig. 1

\begin{tabular}{|c|c|c|c|}
\hline $\begin{array}{r}\text { Station } \\
\text { Date }\end{array}$ & $\begin{array}{c}\mathrm{T} \\
\left({ }^{\circ} \mathrm{C}\right)\end{array}$ & Salinity & $\begin{array}{c}\text { Chlorophyll } \\
\left(\mu \mathrm{g} \mathrm{l}^{-1}\right)\end{array}$ \\
\hline \multicolumn{4}{|l|}{ River } \\
\hline Mar 2001 & 6.5 & 0.1 & 12.2 \\
\hline Jun & 21.5 & 0.1 & 15.6 \\
\hline Aug & 27.6 & 0.1 & 6.1 \\
\hline Dec & 11.9 & 0.1 & 2.3 \\
\hline Mar 2002 & 7.2 & 0.1 & 3.8 \\
\hline \multicolumn{4}{|c|}{ Turbidity Max. } \\
\hline Mar 2001 & 6.8 & 8.7 & 46.9 \\
\hline Jun & 25.0 & 2.9 & 6.5 \\
\hline Aug & 28.4 & 9.4 & 5.4 \\
\hline Dec & 12.9 & 5.6 & 4.5 \\
\hline Mar 2002 & 8.2 & 9.0 & 19.5 \\
\hline \multicolumn{4}{|l|}{ Mid-Bay } \\
\hline Mar 2001 & 6.2 & 15.8 & 32.7 \\
\hline Jun & 22.2 & 15.7 & 12.3 \\
\hline Aug & 27.4 & 16.6 & 3.9 \\
\hline Dec & 11.9 & 21.4 & 8.6 \\
\hline Mar 2002 & 7.8 & 22.0 & \\
\hline \multicolumn{4}{|l|}{ Open Bay } \\
\hline Mar 2001 & 6.2 & 28.5 & 12.5 \\
\hline Jun & 18.1 & 29.8 & 6.1 \\
\hline Aug & 20.9 & 28.5 & 6.1 \\
\hline Dec & 23.1 & 29.8 & 7.5 \\
\hline Mar 2002 & 7.7 & 31.2 & 4.7 \\
\hline
\end{tabular}

\section{Total and bacterial respiration}

Over the entire study, respiration by the bacterial size fraction ( $\%$ bacterial respiration) accounted for $57 \%$ of total respiration (Table 3), although there was much variability with location and season. The percent bacterial respiration tended to be higher at the River and Turbidity Maximum stations than at the 2 bay stations (Table 3), but the relationship with distance was not statistically significant ( $p>0.05)$. Interestingly, there was a significant correlation between bacterial respiration and ${ }^{14} \mathrm{C}$ primary production (Fig. $3 ; \mathrm{r}=0.52$; $\mathrm{p}<0.05, \mathrm{n}=16$ ) even though there was no significant correlation between bacterial production and ${ }^{14} \mathrm{C}$-primary production. A prominent outlyer in the bacterial respiration-primary production relationship is the high respiration value in August at the River station (Fig. 3), but bacterial respiration was not especially high at the other stations in August, and there was no significant correlation between respiration and temperature $(\mathrm{r}=0.341 ; \mathrm{p}>0.05 ; \mathrm{n}=16)$.

Total respiration was significantly correlated to bacterial respiration between March 2001 and March 
Table 2. Thymidine (TdR) and leucine (leu) incorporation and ratio of bacterial production to primary production $\left(P_{\mathrm{b}}: P_{\mathrm{P}}\right)$ in the Delaware Estuary in 2001 and 2002. For each location, highest value was not included in mean. na: not available

\begin{tabular}{|lrcccc|}
\hline $\begin{array}{l}\text { Station } \\
\text { Date }\end{array}$ & $\begin{array}{r}\text { TdR } \\
\left(\mathrm{pM} \mathrm{h}^{-1}\right)\end{array}$ & $\begin{array}{c}\text { leu } \\
\left(\mathrm{pM} \mathrm{h}^{-1}\right)\end{array}$ & $\begin{array}{c}(\mathrm{SD}) \\
\text { River }\end{array}$ \\
\hline Mar 2001 & 17.2 & $(1.0)$ & 196.8 & $(39.5)$ & 0.82 \\
Jun & 111.1 & $(6.2)$ & na & & 0.71 \\
Aug & 146.0 & $(3.4)$ & 595.5 & $(26.0)$ & 0.99 \\
Dec & 189.8 & $(20.5)$ & 221.9 & $(59.0)$ & 27.55 \\
Mar 2002 & 171.5 & $(10.3)$ & 345.4 & $(26.9)$ & 8.52 \\
Mean & & & & & $\mathbf{2 . 7 6}$ \\
& & & & & \\
Turbidity Max. & & & & & \\
Mar 2001 & 15.2 & $(0.5)$ & 151.5 & $(32.9)$ & 0.34 \\
Jun & 30.7 & $(0.1)$ & na & & 0.41 \\
Aug & 57.8 & $(11.9)$ & 350.4 & $(3.7)$ & 0.46 \\
Dec & 28.0 & $(4.9)$ & 55.3 & $(4.1)$ & 1.74 \\
Mar 2002 & 61.3 & $(22.1)$ & 254.6 & $(4.0)$ & 0.27 \\
Mean & & & & & $\mathbf{0 . 6 4}$ \\
& & & & & \\
Mid-Bay & & & & & \\
Mar 2001 & 11.1 & $(1.4)$ & 112.1 & $(7.6)$ & 0.03 \\
Jun & 45.0 & $(3.5)$ & 342.6 & $(14.6)$ & 0.17 \\
Aug & 86.8 & $(16.6)$ & 519.7 & $(59.6)$ & 0.39 \\
Dec & 16.6 & $(13.6)$ & 66.4 & $(3.1)$ & 0.17 \\
Mar 2002 & 15.8 & $(4.4)$ & 243.3 & $(9.9)$ & 0.05 \\
Mean & & & & & $\mathbf{0 . 1 1}$ \\
Open Bay & & & & & \\
Mar 2001 & 5.8 & $(0.6)$ & 134.3 & $(3.5)$ & 0.11 \\
Jun & 29.1 & $(0.8)$ & 464.7 & $(11.6)$ & 0.20 \\
Aug & 145.7 & $(3.4)$ & 1006.0 & $(29.9)$ & 1.11 \\
Dec & 9.4 & $(0.6)$ & na & & 0.21 \\
Mar 2002 & 4.8 & $(0.2)$ & 85.3 & $(1.5)$ & 0.08 \\
Mean & & & & & $\mathbf{0 . 1 5}$ \\
& & & & & \\
\hline
\end{tabular}

2002, when the entire data set was analyzed $(\mathrm{r}=0.59$; $\mathrm{p}<0.05$; $\mathrm{n}=16$ ), and at the River station ( $\mathrm{r}=0.97$; $\mathrm{p}<$ $0.05 ; \mathrm{n}=5$ ). However, there was no correlation between total respiration and respiration by the bacterial size fraction at the Turbidity Maximum, Mid-Bay, or the Open Bay stations ( $\mathrm{r}=0.18,0.57,0.43$, respectively; $\mathrm{p}>0.05 ; \mathrm{n}=5$ ), although the low sample size may explain this lack of significant correlations.

\section{Net oxygen production and impact of bacterial respiration}

Rates of ${ }^{14} \mathrm{C}$ primary production were highly correlated $(\mathrm{r}=0.86 ; \mathrm{p}<0.001 ; \mathrm{n}=43$ ) with net oxygen production in the light bottles when both were expressed per liter (Fig. 4). For these incubations, the $\mathrm{C}: \mathrm{O}_{2}$ ratio was $0.58 \pm 0.054$, according to the slope calculated by a Model II regression analysis. Because stratification of the water column at these stations is

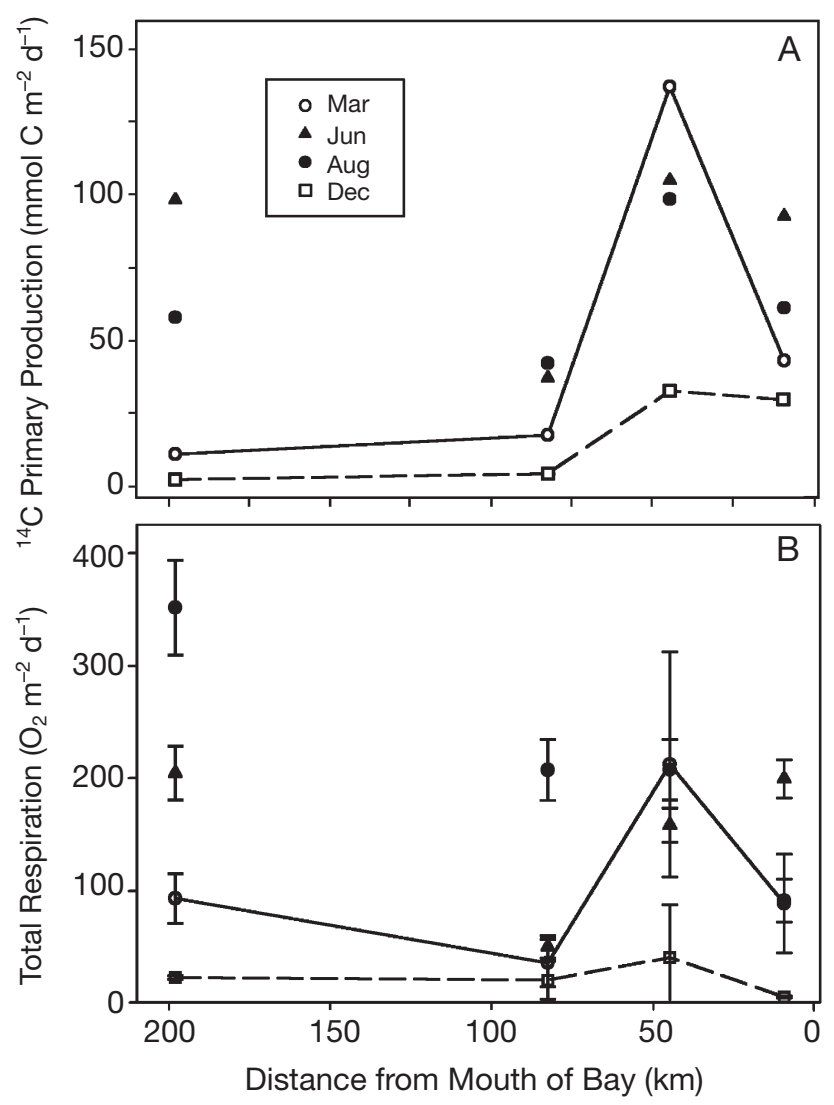

Fig. 2. (A) ${ }^{14} \mathrm{C}$ primary production and (B) total respiration in the Delaware Estuary from March to December 2001. Error bars in (B) represent $\pm 1 \mathrm{SE}$

weak, the integrated rates must take into account respiration in dark regions of the water column where light-dependent production is nil but respiration is still high. Consequently, there was no significant correlation between net oxygen production and ${ }^{14} \mathrm{C}$ primary production for rates integrated over the entire water column $(\mathrm{r}=0.25 ; \mathrm{p}>0.05 ; \mathrm{n}=16)$.

Integrated net oxygen production was negative for many of the stations and seasons examined here (Fig. 5A). The lowest rates (most negative) were at the River station and the highest, including nearly all of the positive net production rates, were at the Open Bay station. Net oxygen production was negative for 3 of the 4 stations in August, the highest number of negative stations of the 4 mo examined. These same 3 stations in August with negative net production also had $<100 \%$ oxygen saturation (Fig. 5B). The correlation between net oxygen production and percent oxygen saturation was $0.49(\mathrm{p}=0.052 ; \mathrm{n}=16)$.

To explore functional relationships between oxygen concentrations and microbial activity in the Delaware Estuary, regression analyses were used to examine 


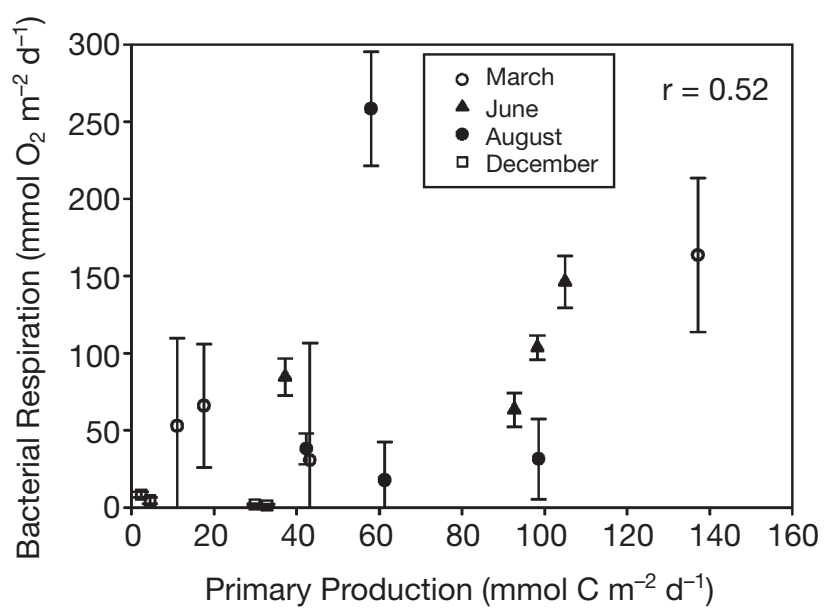

Fig. 3. Bacterial respiration versus ${ }^{14} \mathrm{C}$ primary production from March to December 2001. Correlation is significant $(\mathrm{r}=0.52, \mathrm{p}<0.05)$

Table 3. Contribution (mean $\pm 1 \mathrm{SE}$ ) of bacterial respiration $(<0.8 \mu \mathrm{m}$ size fraction) to total community respiration at 4 stations in the Delaware Estuary from March 2001 to March 2002

\begin{tabular}{|c|c|c|c|}
\hline \multirow{2}{*}{$\begin{array}{r}\text { Station } \\
\text { Date }\end{array}$} & \multicolumn{2}{|c|}{ Respiration $\left(\mathrm{mmol} \mathrm{O}_{2} \mathrm{~m}^{-2} \mathrm{~d}^{-1}\right)$} & \multirow{2}{*}{$\begin{array}{l}\text { Bact:Total } \\
\text { respiration }\end{array}$} \\
\hline & Total & Bacterial & \\
\hline \multicolumn{4}{|l|}{ River } \\
\hline Mar 2001 & $92.7 \pm 22$ & $52.8 \pm 57$ & $0.57 \pm 0.6$ \\
\hline Jun & $204.2 \pm 24$ & $103.5 \pm 8$ & $0.51 \pm 0.1$ \\
\hline Aug & $351.2 \pm 42$ & $258.4 \pm 37$ & $0.74 \pm 0.1$ \\
\hline Dec & $22.5 \pm 1.5$ & $8.2 \pm 1.9$ & $0.37 \pm 0.1$ \\
\hline Mar 2002 & $121.9 \pm 29$ & $49.0 \pm 67$ & $0.40 \pm 0.6$ \\
\hline Mean & & & 0.52 \\
\hline \multicolumn{4}{|c|}{ Turbidity Max. } \\
\hline Mar 2001 & $35.5 \pm 21$ & $65.9 \pm 40$ & $1.86 \pm 1.6$ \\
\hline Jun & $49.7 \pm 10$ & $84.6 \pm 12$ & $1.70 \pm 0.4$ \\
\hline Aug & $207.1 \pm 27$ & $38.0 \pm 10$ & $0.18 \pm 0.1$ \\
\hline Dec & $20.1 \pm 17$ & $4.5 \pm 2.1$ & $0.22 \pm 0.2$ \\
\hline Mar 2002 & $326.4 \pm 75$ & $35.7 \pm 46$ & $0.11 \pm 0.1$ \\
\hline Mean & & & 0.81 \\
\hline \multicolumn{4}{|l|}{ Mid-Bay } \\
\hline Mar 2001 & $212.0 \pm 100$ & $163.5 \pm 50$ & $0.77 \pm 0.4$ \\
\hline Jun & $157.9 \pm 15$ & $146.2 \pm 17$ & $0.93 \pm 0.1$ \\
\hline Aug & $207.1 \pm 27$ & $31.4 \pm 26$ & $0.15 \pm 0.1$ \\
\hline Dec & $40.2 \pm 47$ & $1.3 \pm 0.8$ & $0.03 \pm 0.04$ \\
\hline Mar 2002 & $190.9 \pm 36$ & $211.6 \pm 48$ & $1.11 \pm 0.3$ \\
\hline Mean & & & 0.60 \\
\hline \multicolumn{4}{|l|}{ Open Bay } \\
\hline Mar 2001 & $88.2 \pm 44$ & $30.6 \pm 76$ & $0.35 \pm 0.9$ \\
\hline Jun & $199.0 \pm 17$ & $63.2 \pm 11$ & $0.32 \pm 0.1$ \\
\hline Aug & $90.8 \pm 19$ & $17.5 \pm 25$ & $0.19 \pm 0.3$ \\
\hline Dec & $5.1 \pm 1$ & $1.9 \pm 0.5$ & $0.37 \pm 0.1$ \\
\hline Mar 2002 & $0.7 \pm 29$ & $59.5 \pm 16$ & $89 \pm 4000$ \\
\hline Mean $^{\mathrm{a}}$ & & & 0.31 \\
\hline
\end{tabular}

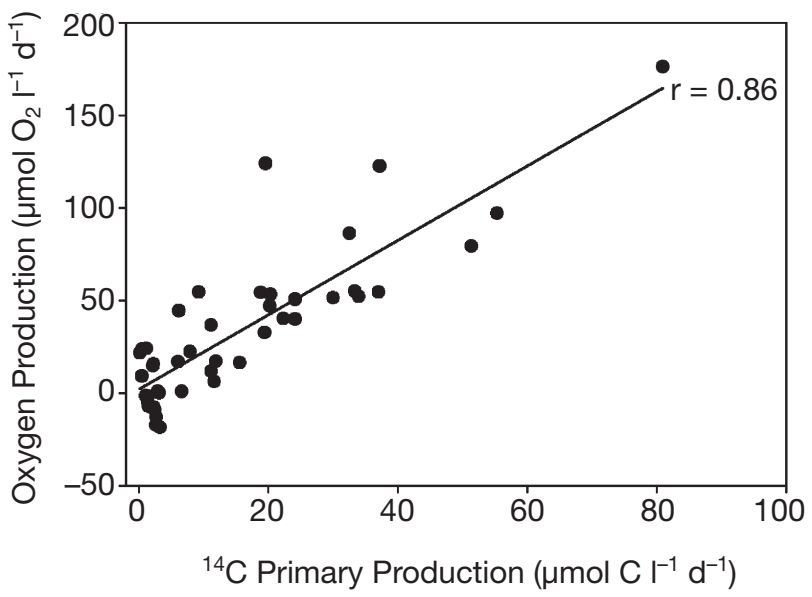

Fig. 4. Volumetric rates of ${ }^{14} \mathrm{C}$ primary production versus net oxygen production (light bottles) from March to December 2001. Correlation is significant $(\mathrm{r}=0.86, \mathrm{p}<0.05)$. Line is from Model II regression analysis, and $\mathrm{C}: \mathrm{O}_{2}$ ratio implied by slope $=0.58 \pm 0.054$

variation in oxygen saturation as a function of both bacterial production (average of TdR and leu incorporation-based estimates) and primary production. In 1986 to 1988 , the regression analysis indicated that primary production had a positive impact and bacterial production a negative impact on oxygen saturation (Table 4). In 2001-2002, the amount of variation described by the regression model was higher than in 1986-1988 $\left(\mathrm{r}^{2}=0.372\right.$ versus 0.272$)$, but the regression coefficients were lower. In fact, the impact of primary production was statistically insignificant whereas bacterial production still had a significant, negative impact on oxygen saturation (Table 4).

\section{DISCUSSION}

Based on low dissolved oxygen and high $\mathrm{CO}_{2}$ partial pressure measurements, Sharp et al. (1982) suggested that the upper Delaware Estuary was dominated by heterotrophic processes and the lower portion of the estuary (salinity $>10$ ) by autotrophic processes. Consistent with Sharp et al. (1982), Hoch \& Kirchman (1993) found bacterial production to exceed primary production in the upper portion of the Delaware Estuary. With the exception of Lipschultz et al. (1986), the balance between heterotrophy and autotrophy in the Delaware Estuary has been examined only indirectly (Culberson 1988). Our study measured both total and bacterial respiration and oxygen production directly in a series of light and dark incubations to determine and better understand the factors controlling net community production in the Delaware Estuary. We found that the freshwater station was heterotrophic and that 
Table 4. Regression analyses of impact of ${ }^{14} \mathrm{C}$ primary production $\left(P_{\mathrm{P}}\right)$ and bacterial production $\left(P_{\mathrm{b}}\right)$ on percent oxygen saturation (OS). Regression model was: OS $=a P_{\mathrm{P}}+b P_{\mathrm{b}}+$ constant. Values are the coefficients $a$ and $b$ (and associated errors), indicating relative contribution of $P_{\mathrm{p}}$ and $P_{\mathrm{b}}$ in determining variation in OS. $P_{\mathrm{b}}$ was determined from average of TdR and leu incorporation. ${ }^{*} \mathrm{p}<0.05$

\begin{tabular}{ccccccc|}
\hline Years & $P_{\mathrm{P}}$ & Error & $P_{\mathrm{b}}$ & Error & $\mathrm{n}$ & $\mathrm{r}^{2}$ \\
\hline $1986-1988$ & $0.113^{*}$ & 0.013 & $-0.500^{*}$ & 0.055 & 302 & 0.272 \\
$2001-2002$ & 0.061 & 0.080 & $-0.129^{*}$ & 0.047 & 15 & 0.372 \\
\hline
\end{tabular}

net community production increased down the estuary, becoming near-balanced to autotrophic at the Mid-Bay and Open Bay stations.

Our rates of microbial production and respiration and the contribution of bacteria to both processes appear to be similar to those observed previously in the Delaware (Lipschultz et al. 1986, Pennock \& Sharp 1986, Coffin \& Sharp 1987, Hoch \& Kirchman 1993) and Chesapeake (Smith \& Kemp 2001) Bays. Some observations, however, were not expected or may not be consistent with our current understanding of microbial dynamics. Most obviously, bacterial respiration exceeding total respiration, measured occasionally in the Turbidity Maximum and once in the Open Bay station, is clearly impossible.

Respiration rates of the bacterial size fraction also exceeded those of the unfiltered community in 2 previous studies of estuarine waters in Georgia (Hopkinson et al. 1989, Griffith et al. 1990), suggesting problems with the size fractionation procedure. Filtration obviously alters predator-prey interactions (Pomeroy et al. 1994) and can lead to the release of inorganic and organic substrates if cells are broken during filtration. Both processes could lead to rates of the bacterial size fraction exceeding those of the total community. Recently, Obernosterer et al. (2003) pointed out the opposite problem, that size fractionation leads to underestimates of bacterial respiration, although their study was in the Sargasso Sea, where the impact of size fractionation may differ from that in estuaries such as the Delaware. Other data provide support for our estimates of bacterial respiration. The linear decreases in oxygen during the incubations suggest that size fractionation artifacts were not substantial. This conclusion is also supported by measurements of thymidine and leucine incorporation during a typical respiration experiment (Preen 2003) and by growth efficiency estimates (see below).

Our estimates of bacterial respiration can also be evaluated in the light of other data on primary and bacterial production and net community production. Over the 4 seasons and 4 locations examined, we observed

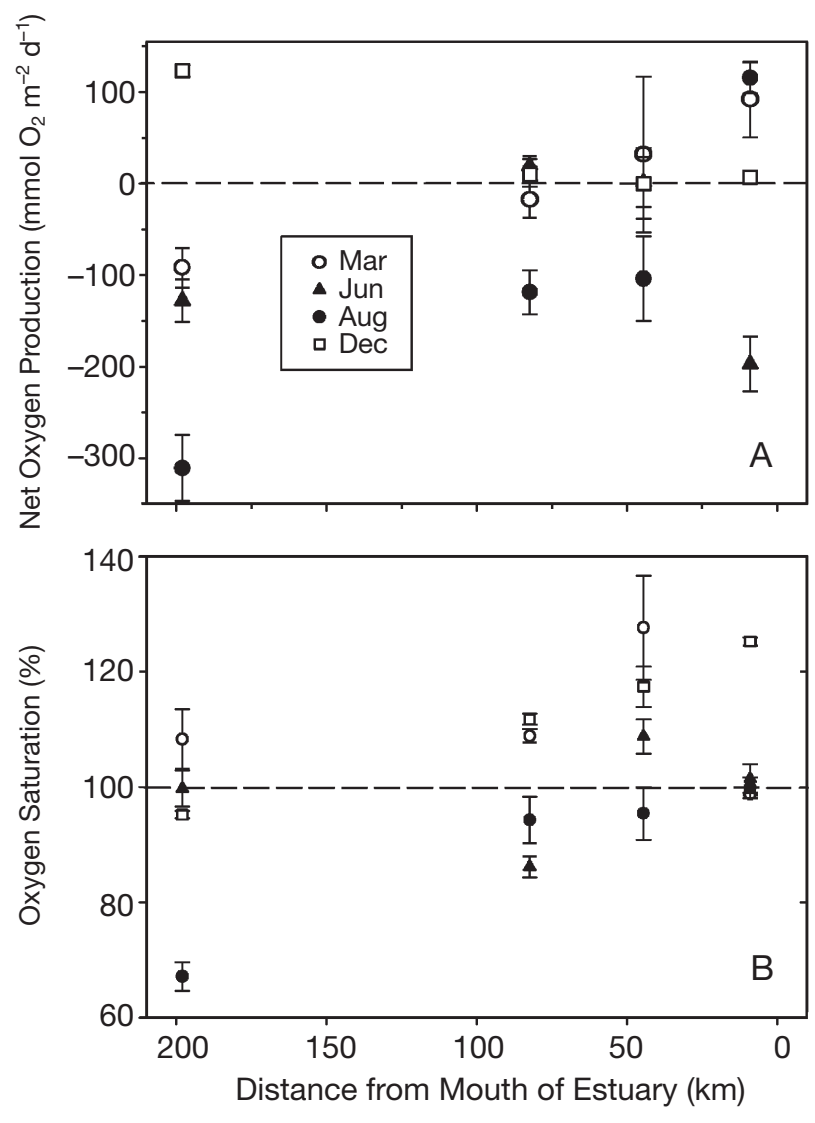

Fig. 5. (A) Net oxygen production (mean $\pm 1 \mathrm{SE}$ ) and (B) percent oxygen saturation (mean $\pm 1 \mathrm{SE}$ ) from March to December 2001. Dashed lines: no net production, 100\% saturation

several combinations of high and low rates of bacterial production, primary production, total respiration and net oxygen production. To explore the implications of this variation, we compiled a simple mass balance of the critical processes (Fig. 6). The key is recognizing that bacterial activity is fueled by terrestrial organic material $(T)$ and by some fraction $(f)$ of primary production $\left(P_{\mathrm{p}}\right)$; any production of DOM by other organisms (e.g. zooplankton grazing and viral lysis) is subsumed in the term used for DOM production directly by phytoplankton $\left(f P_{\mathrm{p}}\right)$. Bacterial production $\left(P_{\mathrm{b}}\right)$ therefore is:

$$
P_{\mathrm{b}}=\left(T+f P_{\mathrm{p}}\right) Y
$$

where $Y$ is the bacterial growth efficiency. Eq. (1) is correct regardless of what limits bacterial production rates. Bacterial respiration $\left(R_{\mathrm{b}}\right)$ then is:

$$
R_{\mathrm{b}}=P_{\mathrm{b}}(1-Y) / Y
$$

One important assumption is that primary production and terrestrial carbon is complete degraded and respired. That is, total respiration $(R)$ can be calculated as: 


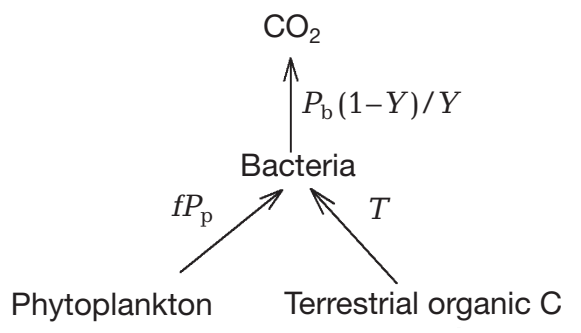

Fig. 6. Bacterial production $\left(P_{\mathrm{b}}\right)$ and respiration as a function of growth efficiency $(Y)$, the fraction $(f)$ of primary production $\left(P_{\mathrm{p}}\right)$ routed through bacteria $\left(f P_{\mathrm{p}}\right)$, and terrestrial organic carbon $(T)$

$$
R=T+P_{\mathrm{p}}
$$

This assumption, represented by Eq. (3), is a useful simplification for budget calculations designed to examine respiration-production relationships, but not export or storage of primary production and terrestrial carbon. In effect, $T$ refers to labile, not total terrestrial organic material transported into the estuary. Based on Eqs. (2) \& (3), the ratio $\left(R_{\mathrm{b}}: R\right)$ of bacterial respiration $\left(R_{\mathrm{b}}\right)$ to total respiration $(R)$ is:

$$
R_{\mathrm{b}}: R=P_{\mathrm{b}} \frac{(1-Y) / Y}{T+P_{\mathrm{P}}}
$$

To simply this analysis, primary production was fixed at $55 \mathrm{mmol} \mathrm{C} \mathrm{m}^{-2} \mathrm{~d}^{-1}$, which is the average for the Delaware Estuary during this study. Bacterial production and respiration were calculated as a function of $T$ with various combinations of the growth efficiency and the fraction of primary production routed to heterotrophic bacteria $(f)$.

In the budget calculations, bacterial production and thus the ratio of bacterial production to primary production $\left(P_{\mathrm{b}}: P_{\mathrm{p}}\right)$ increase as a direct linear function of terrestrial organic carbon and of the fraction of primary production processed by bacteria $(f)$ and inversely with $Y$ (not shown). Also, as expected, bacterial respiration increases as the input of terrestrial organic carbon increases. What may be surprising is that the ratio of bacterial to total respiration $\left(R_{\mathrm{b}}: R\right)$ is insensitive (the curve becomes flat) to increases in labile terrestrial carbon beyond the primary production rate (Fig. 7A). This ratio of respiration rates cannot increase indefinitely because even a low bacterial growth efficiency ensures some respiration by other organisms; any biomass production by bacteria is respired by bacterivores. More precisely, $R_{\mathrm{b}}: R$ approaches $(1-Y)$ as $T$ increases substantially past $P_{\mathrm{p}}$. The calculated $R_{\mathrm{b}}: R$ was also plotted against the ratio of bacterial production to primary production $\left(P_{\mathrm{b}}: P_{\mathrm{p}}\right)$ to facilitate comparisons between the budget calculations and actual data (Fig. 7B).

Fig. 7B highlights some observations that are not consistent with our current understanding of microbial dynamics. At the Mid-Bay station, $R_{\mathrm{b}}: R$ appears to be too high (0.77 to 0.93) in March and June 2001 for the measured $P_{\mathrm{b}}: P_{\mathrm{p}}$ ratio $(<0.25)$ unless the bacterial growth efficiency was very low $(Y=0.05)$, much lower than that commonly observed in estuaries (del Giorgio $\&$ Cole 2000). In addition to the problematic growth efficiency, the input of terrestrial organic material
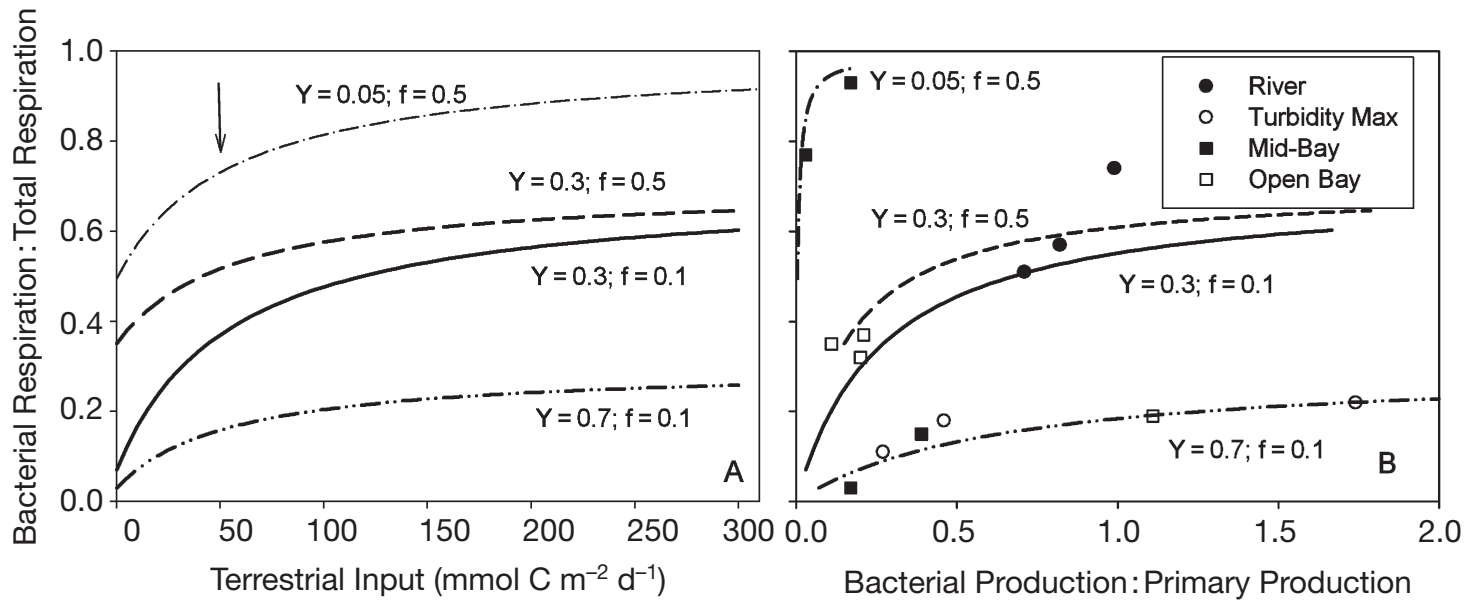

Fig. 7. Budget of respiration, biomass production $\left(P_{\mathrm{b}}\right)$ and terrestrial organic carbon $(T)$. (A) Relative bacterial respiration as a function of terrestrial organic carbon input in model; arrow indicates average of primary production in the Delaware Estuary during the study and rate used in budget calculations. $Y=$ bacterial growth efficiency; $f=$ fraction of primary production $\left(P_{\mathrm{p}}\right)$ routed to bacteria. (B) Relative bacterial respiration and production $\left(P_{\mathrm{b}}\right)$ in model (data lines) and data from the Delaware (data points); lines were generated by calculating respiration and production ratios as a function of $T$ for given $Y$ and $f_{\text {; }}$ terrestrial input $(T)$ was zero at left end of line (lowest $P_{\mathrm{b}}: P_{\mathrm{p}}$ ) and $300 \mathrm{mmol} \mathrm{C} \mathrm{m}^{-2} \mathrm{~d}^{-1}$ at right end (highest $P_{\mathrm{b}}: P_{\mathrm{p}}$ ), except for maximum $T$ in 2 cases: for $Y=0.05$ and $f=0.5$, maximum $T=1000 \mathrm{mmol} \mathrm{C} \mathrm{m}^{-2} \mathrm{~d}^{-1}$; for $Y=0.7$ and $f=0.1$, maximum $T=152 \mathrm{mmol} \mathrm{C} \mathrm{m}^{-2} \mathrm{~d}^{-1}$ 
(TOM) needed to support the implied bacterial respiration is high (100 to $>500 \mathrm{mmol} \mathrm{C} \mathrm{m}^{-2} \mathrm{~d}^{-1}$ ), probably too high for the Mid-Bay station. For 2 other months (August and December) there is the opposite problem; the $R_{\mathrm{b}}: R$ ratio is too low (0.03 and 0.15) in the Mid-Bay station unless the growth efficiency is much higher than the norm $(Y=0.7)$. The values for the Turbidity Maximum station are also problematic, even ignoring 2 mo in which $R_{\mathrm{b}}: R$ exceeded 1 . In 2 other months at this station, $R_{\mathrm{b}}: R$ is again too low unless $Y$ was abnormally high. In short, the data on bacterial production and respiration at these 2 stations are consistent with each other only by assuming unusual growth efficiencies.

Of course, there is much variation around reported 'average' growth efficiencies, especially in rivers and estuaries (Chin-Leo \& Benner 1992, del Giorgio \& Bouvier 2002). Respiration or production may be temporarily low or high because of unbalanced growth (Chin-Leo \& Kirchman 1990), leading to growth efficiencies being unusually low or high for short time periods. We do know that different factors potentially affect respiration and biomass production (Smith \& Kemp 2003) and, likewise, we observed that bacterial respiration (but not biomass production) was significantly correlated with primary production. Jensen et al. (1990), on the other hand, observed positive correlations among bacterial respiration, production, and primary production in a Danish estuary. It seems reasonable to suppose that the ratio of respiration to production and thus growth efficiency could vary, perhaps only temporarily, far from the grand averages for the system. However, we cannot forget that there are many problems in measuring bacterial production from thymidine and leucine incorporation, and the high bacterial respiration observed at the Mid-Bay station and the low rates measured at the Turbidity Maximum station could be artifacts of size fractionation.

Nitrification is another bacterially mediated process that would lead to discrepancies and apparent inconsistencies. Oxygen consumption by nitrification would affect the relationship between production and respiration, especially if nitrifying bacteria do not incorporate thymidine and leucine. Nitrification has been shown to make substantial contributions to oxygen demands in some estuarine systems (Pakulski et al. 1995) and minor contributions in others (Owens 1986). There is some evidence that nitrification has a large impact on oxygen in the Delaware River at least (Cifuentes et al. 1989), and water quality models assume that it does. Nitrification could explain why our respiration values were so high in the River. Lipschultz et al. (1986) concluded, however, that oxygen depletion in the Delaware reflected heterotrophic respiration rather than nitrification, because they found that nitrification was substantial, relative to heterotrophic respiration, at only 1 station in the Delaware River. They did not measure respiration and nitrification in the marine regions of the estuary. Dark ${ }^{14} \mathrm{CO}_{2}$ fixation rates measured during our study also suggest that rates of nitrification were not high relative to heterotrophic bacterial activity (Preen 2003).

Although Fig. 7B points to some potentially problematic data, it also highlights data that appear consistent with our understanding of microbial dynamics. Bacterial respiration rates in the Open Bay station are consistent with a high but realistic growth efficiency $(Y$ $=0.3$ ) and either a low (0.1) or high (0.5) fraction of in situ primary production being routed to bacteria $(f)$. To account for the observed respiration and production ratios $\left(R_{\mathrm{b}}: R\right.$ and $\left.P_{\mathrm{b}}: P_{\mathrm{p}}\right)$, the input of labile TOM has to

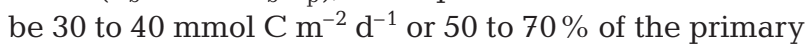
production rate, if the low fraction $(f=0.1)$ is assumed. Such a large input of TOM would result in negative oxygen production, which was not usually observed at this station; production was usually positive at the Open Bay station. It seems more likely that TOM input is relatively low at the Open Bay station and that the fraction of in situ primary production processed by bacteria is closer to the canonical $50 \%$ ( $\mathrm{f}=0.5$ ). If so, then the Open Bay station is similar to the open ocean habitats modeled by Anderson \& Ducklow (2001), with the important exception that the $P_{\mathrm{b}}: P_{\mathrm{p}}$ ratio is higher $(0.2)$ than commonly observed in the open ocean $(0.1)$. If labile TOM inputs are assumed to be minimal, which would be consistent with the positive oxygen production at this station, then these high $P_{\mathrm{b}}: P_{\mathrm{p}}$ values indicate that the bacterial growth efficiency is relatively high $(Y=0.3)$ in this region of the estuary (Fig. 7B).

Fig. 7B also indicates that bacterial respiration and production at the River station appear consistent with our current notions of $Y$ and $f$. The data are consistent with either value assumed for $f$, although the high $R_{\mathrm{b}}: R$ value in August is closer to the case of $f=0.5$ than with $f=0.1$ (Fig 7B). As with the Open Bay station, the budget indicates that the growth efficiency is high ( $Y=$ $0.3)$. On the one hand, such a high growth efficiency is not surprising, given that the average growth efficiency for all other estuaries is $37 \%(Y=0.37)$ (del Giorgio \& Cole 2000), similar to our own estimates for the Delaware: the average growth efficiency estimated from our bacterial production data and bacterial respiration was $43 \%$ for the River station and $35 \%$ for the entire Delaware Estuary. On the other hand, we would not have expected such a high growth efficiency for the River station, where labile TOM inputs seem to be very high (see below). This high growth efficiency would seem unusual, because one would expect bacterial growth on presumed recalcitrant organic material from terrestrial sources to be inefficient. However, 
Benner et al. (1988) reported growth efficiencies for bacteria using lignin-cellulose, the archetypical terrestrial organic compound, of about $30 \%$. Growth may be slow on TOM, but it is not necessarily inefficient. Of course, TOM is a complex mixture of compounds that bacteria use at different rates and efficiencies.

In addition to a high growth efficiency at the River station, the high relative bacterial production rates $\left(P_{\mathrm{b}}: P_{\mathrm{p}}>0.7\right)$ are only possible if TOM inputs are also very large (100 to $150 \mathrm{mmol} \mathrm{C} \mathrm{m}^{-2} \mathrm{~d}^{-1}$ ), 2- to 3 -fold greater than primary production. This substantial input of TOM is consistent with data indicating that net oxygen production was usually negative at the River station. In addition, the magnitude of net oxygen production at this station ( -300 to $-100 \mathrm{mmol} \mathrm{O}_{2}$ $\mathrm{m}^{-2} \mathrm{~d}^{-1}$ versus 100 to $150 \mathrm{mmol} \mathrm{C} \mathrm{m}{ }^{-2} \mathrm{~d}^{-1}$ ) also is consistent with the budget calculations, and seems consistent with the limited data on TOM in the Delaware Estuary.

Although TOM inputs for the Delaware Estuary have not been estimated (J. Sharp pers. comm.), a rough estimate is possible using the concentration of 1 tracer of TOM, lignin, and the flow of the Delaware River. The input of lignin and thus TOM should be roughly equal to the observed concentration multiplied by the river flow, or else the river would remove all lignin and TOM from the system, assuming steady-state. Mannino \& Harvey (2000) found dissolved high molecular weight lignin to be about $0.5 \mathrm{mg} \mathrm{C} \mathrm{m}^{-3}$ in the Delaware Bay and estimated TOM to be $80 \mathrm{mg} \mathrm{C} \mathrm{m}^{-3}$. Since the buoyancy current of the Delaware River Estuary is on the order of $10 \mathrm{~cm} \mathrm{~s}^{-1}$ (Wong \& Muenchow 1995), the input of riverine TOM would have to several moles of organic carbon $\mathrm{m}^{-2} \mathrm{~d}^{-1}$. This calculation gives the rate of TOM removal by transport and does not include any TOM used by bacteria. Kemp et al. (1997) estimated that allochthonous organic carbon inputs to the upper Chesapeake Bay was on the order of $40 \mathrm{mmol} \mathrm{C} \mathrm{m}{ }^{-2}$ $\mathrm{d}^{-1}$. The input of allochthonous organic carbon needed to support estimates of bacterial respiration in the

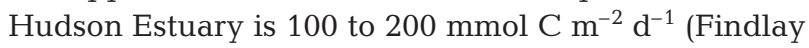
et al. 1998). These calculations and comparisons suggest that the input of TOM into the Delaware River (on the order of $100 \mathrm{mmol} \mathrm{C} \mathrm{m}^{-2} \mathrm{~d}^{-1}$ ) is sufficient to support observed rates of respiration and biomass production and is consistent with the observed degree of oxygen saturation.

The input of TOM undoubtedly has several impacts on biogeochemical cycles in the Delaware. It is perhaps because of TOM that bacterially mediated processes appear to have a greater role than primary production in determining oxygen concentrations in the Delaware, as suggested by the regression analysis of biomass production and oxygen saturation (Table 4). The data used in the regression analysis are not direct estimates of oxygen production and use (e.g. bacterial production, not respiration, was analyzed), but they are undoubtedly indicative, as illustrated in this study, of processes that affect oxygen dynamics in the estuary. Of course, physical factors affecting gas exchange also have a large impact and explain why the 2 biological processes did not account for more of the variation in oxygen concentrations. The regression analysis also suggests that the impacts of in situ heterotrophic and autotrophic processes on oxygen saturation have changed over the last $15 \mathrm{yr}$ the role of primary production may have decreased while that of heterotrophic bacteria has remained significant. These microbial processes are undoubtedly influenced by variations in TOM and inorganic nutrient inputs caused by changes in land use in the Delaware watershed during the last $15 \mathrm{yr}$. The impact of inorganic nutrients in estuaries is well known, but our study indicates that TOM could also have a substantial impact on oxygen and probably other biogeochemical cycles in estuaries like the Delaware.

Acknowledgements. We thank Matt Cottrell and Rex Malmstrom for their help during this study, Alex Parker for his comments on the paper, and Jon Sharp for allowing us to use unpublished data for the Delaware Estuary. This work was supported by the National Science Foundation (OCE9908808).

\section{LITERATURE CITED}

Anderson TR, Ducklow HW (2001) Microbial loop carbon cycling in ocean environments studied using a simple steady-state model. Aquat Microb Ecol 26:37-49

Benner R, Lay J, K'nees E, Hodson RE (1988) Carbon conversion efficiency for bacterial growth on lignocellulose: implications for detritus-based food webs. Limnol Oceanogr 33:1514-1526

Chin-Leo G, Benner R (1992) Enhanced bacterioplankton production and respiration at intermediate salinities in the Mississippi River plume. Mar Ecol Prog Ser 87:87-103

Chin-Leo G, Kirchman DL (1990) Unbalanced growth in natural assemblages of marine bacterioplankton. Mar Ecol Prog Ser 63:1-8

Cifuentes LA, Fogel ML, Pennock JR, Sharp JH (1989) Biogeochemical factors that influence the stable nitrogen isotope ratio of dissolved ammonium in the Delaware Estuary. Geochim Cosmochim Acta 53:2713-2721

Coffin RB, Sharp JH (1987) Microbial trophodynamics in the Delaware Estuary. Mar Ecol Prog Ser 41:253-266

Cole JJ, Pace ML (1995) Why measure bacterial productionreply. Limnol Oceanogr 40:441-444

Culberson CH (1988) Dissolved oxygen, inorganic carbon, and the acid-base system in the Delaware Estuary. In: Majumdar SK, Miller WW, Sage LE (eds) Ecology and restoration of the Delaware River Basin. Pennsylvania Academy of Science, Easton, PA, p 58-76

del Giorgio PA, Bouvier TC (2002) Linking the physiologic and phylogenetic successions in free-living bacterial communities along an estuarine salinity gradient. Limnol Oceanogr 47:471-486 
del Giorgio PA, Cole JJ (2000) Bacterial energetics and growth efficiency. In: Kirchman DL (ed) Microbial ecology of the ocean. Wiley-Liss, New York, p 289-325

Ducklow HW, Shiah FK (1993) Bacterial production in estuaries. In: Ford TE (ed) Aquatic microbiology: an ecological approach. Blackwell Scientific Publications, Boston, MA, p 261-287

Findlay S, Sinsabaugh RL, Fischer DT, Franchini P (1998) Sources of dissolved organic carbon supporting planktonic bacterial production in the tidal freshwater Hudson River. Ecosystems 1:227-239

Fuhrman JA, Azam F (1980) Bacterioplankton secondary production estimates for coastal waters of British Columbia, Antarctica, and California. Appl Environ Microbiol 39: 1085-1095

Griffith PC, Douglas DJ, Wainright SC (1990) Metabolic activity of size fractionated microbial plankton in estuarine, nearshore, and continental shelf waters of Georgia. Mar Ecol Prog Ser 59:263-270

Hoch MP, Kirchman DL (1993) Seasonal and interannual variability in bacterial production and biomass in a temperate estuary. Mar Ecol Prog Ser 98:283-295

Hopkinson CS, Sherr B, Wiebe WJ (1989) Size fractionated metabolism of coastal microbial plankton. Mar Ecol Prog Ser 51:155-166

Jahnke RA, Craven DB (1995) Quantifying the role of heterotrophic bacteria in the carbon cycle: a need for respiration rate measurements. Limnol Oceanogr 40:436-441

Jensen LM, Sand-Jensen K, Marcher S, Hansen M (1990) Plankton community respiration along a nutrient gradient in a shallow Danish estuary. Mar Ecol Prog Ser 61:75-85

Kemp WM, Smith EM, Marvin-DiPasquale M, Boynton WR (1997) Organic carbon balance and net ecosystem metabolism in Chesapeake Bay. Mar Ecol Prog Ser 150:229-248

Kirchman DL (2001) Measuring bacterial biomass production and growth rates from leucine incorporation in natural aquatic environments. In: Paul JH (ed) Marine microbiology, Vol 30. Academic Press, San Diego, CA, p 227-237

Lipschultz F, Wofsy SC, Fox LE (1986) Nitrogen metabolism of the eutrophic Delaware River ecosystem. Limnol Oceanogr 31:701-716

Mannino A, Harvey HR (2000) Terrigenous dissolved organic matter along an estuarine gradient and its flux to the coastal ocean. Org Geochem 31:1611-1625

Obernosterer I, Kawasaki N, Benner R (2003) P-limitation of respiration in the Sargasso Sea and uncoupling of bacteria

Editorial responsibility: Bess Ward,

Princeton, New Jersey, USA from P-regeneration in size fractionation experiments. Aquat Microb Ecol 32:229-237

Owens NJP (1986) Estuarine nitrification: a naturally occurring fluidized bed reaction? Estuar Coast Shelf Sci 21:711-725

Pakulski JD, Benner R, Amon R, Eadie B, Whitledge T (1995) Community metabolism and nutrient cycling in the Mississippi River plume-evidence for intense nitrification at intermediate salinities. Mar Ecol Prog Ser 117:207-218

Pennock JR, Sharp JH (1986) Phytoplankton production in the Delaware Estuary: temporal and spatial variability. Mar Ecol Prog Ser 34:143-155

Pomeroy LR, Sheldon JE, Sheldon WMJ (1994) Changes in bacterial numbers and leudine assimilation during estimations of microbial respiratory rates in seawater by the precision Winkler method. Appl Environ Microbiol 60: 328-332

Preen KE (2003) Net community production and bacterial respiration in the Delaware Estuary. MSc thesis, University of Delaware, Lewes, DE

Revilla M, Ansotegui A, Iriarte A, Madariaga I, Orive E, Sarobe A, Trigueros JM (2002) Microplankton metabolism along a trophic gradient in a shallow-temperate estuary. Estuaries 25:6-18

Sharp JH, Culberson CH, Church TM (1982) The chemistry of the Delaware Estuary: general considerations. Limnol Oceanogr 27:1015-1028

Smith DC, Azam F (1992) A simple, economical method for measuring bacterial protein synthesis in seawater using ${ }^{3}$ H-leucine. Mar Microb Food Webs 6:107-114

Smith EM, Kemp WM (1995) Seasonal and regional variations in plankton community production and respiration for Chesapeake Bay. Mar Ecol Prog Ser 116:217-231

Smith EM, Kemp WM (2001) Size structure and the production/respiration balance in a coastal plankton community. Limnol Oceanogr 46:473-485

Smith EM, Kemp WM (2003) Planktonic and bacterial respiration along an estuarine gradient: responses to carbon and nutrient enrichment. Aquat Microb Ecol 30:251-261

Smith SV, Hollibaugh JT (1993) Coastal metabolism and the oceanic organic-carbon balance. Rev Geophys 31:75-89

Williams PJl (2000) Heterotrophic bacteria and the dynamics of dissolved organic material. In: Kirchman DL (ed) Microbial ecology of the oceans. Wiley-Liss, New York, p 153-200

Wong KC, Muenchow A (1995) Buoyancy forced interaction between estuary and inter shelf observation. Cont Shelf Res 15:59-88

Submitted: February 4, 2004; Accepted: July 19, 2004

Proofs received from author(s): November 8, 2004 